\title{
The reform research of colleges and universities sports teaching under the mobile Internet platform
}

\author{
Yang Wu, Binhua Zhang and Qiaozhen Yan \\ Wenshan university, school of physical, Wenshan 663000, China \\ angwu@163.com
}

Keywords: Multimedia technology platform, College Physical Education, Online education

\begin{abstract}
With the development of computer technology, multimedia technology, communication technology in our country, there has been a new educational model of educational technology, where multimedia network teaching is a very prominent part. In this paper, on the basis background of the theory and development of multimedia network teaching, how multimedia network teaching platform promote the needs of the College Physical Education is analyzed, and related technologies applied to application is also analyzed, as well as the use of each module and Planning more related presentations. Standard multimedia network teaching platform design guidelines, it discussed design criteria for the sports disciplines multimedia online education platform, and the overall structure of the model is given.
\end{abstract}

\section{Introduction}

With the popularity of the Internet and the all-round development of the computer information technology, campus network teaching of colleges and universities own increasingly developed, more and more students start to use the web channel for their own learning as well as the relevant work. Network teaching makes full advantage of its outstanding role in the daily teaching, and the subject scope is more and more widely. The promotion of multimedia network teaching platform in the sports teaching in colleges makes the universities sports teaching resources sharing. What's more, complementary advantages between universities have broken the traditional concept of college students in physical education learning, which let the university students' understanding of sports and learning reach a new height. Chen Zebing expounded in the network education and modern distance education of sports from two aspects of advantages and disadvantages respectively for traditional PE teaching mode and the sports teaching under the multimedia network teaching [1-2].

\section{The research methods}

Network survey. Through searching the network and browsing the website, we can master the application scope and situations of multimedia network teaching platform on the subject of the teaching in colleges and universities at home and abroad, especially the application in physical education teaching direction is more obvious. And by browsing access relevant authoritative department official website for the latest data released, then it can provide reference basis for the paper writing.

Mathematical statistics. Data information from the Network and he literature is make a data statistics by Microsoft Excel2003 software, and then we will analyze the relevant data.

Logical analysis. Through the literature retrieval and network query to get the relevant data and make a logic analysis, the problems of multimedia network teaching platform in the sports teaching when they are promoted has carried on the induction and collation, includes its promotion strategy. 
The promotion of Multimedia network teaching platform in the sports teaching in colleges and universities

Basic structure and working principle of college multimedia network sports teaching platform. Multimedia network teaching platform adopts the latest B/S structure, which is shown in figure 1. The characteristics of the structure is as follows: the client application environment is the standardized general Web browser, and all the applications are stored on a Web server, when someone needs, he can be directly downloaded. And it is more easy to manage and maintain. This structure has good expansibility and openness.

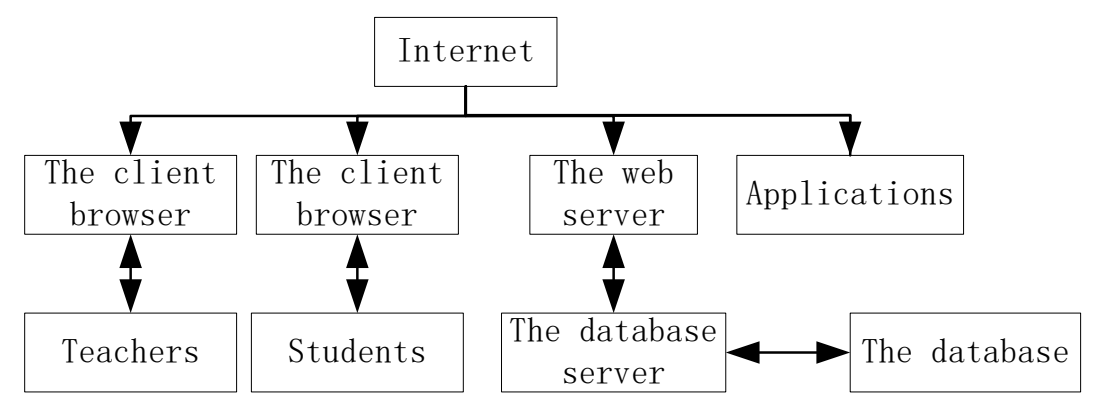

Fig. 1 Structure of multimedia network teaching platform

The working principle of this system is as follows: teachers and students through the browser to access the multimedia network teaching platform. Students use personal computer equipment to connect to the server via a browser, then they can carry on the related sports in teaching contents and learning resource information query such as the timely communication between teachers and students, personal data uploading operation etc.. The manager of multimedia network teaching platform and college sports teachers can update content stored in the server through the browser and the maintenance. And the latest sports teaching resource information is uploaded to the server side, at the same time, it can be achieved with the student online and can make sports guidance to students. Server consists of a web server and database server. Where web server stores all kinds of application modules to the system, it is used to complete the application functions of customer. It receives the user's request and translate it into a database request after interaction with the database server. Database server storage database and its management software required by the system, it according to the request from the Web server to make database operation. Finally, the results is transported to the Web server.

The support environmental structure of college sports multimedia network teaching platform. The promotion of multimedia network teaching platform in the sports teaching in colleges and universities, it is indispensable to the construction of the platform environment. According to the technical specification for modern distance education resource construction of support system of modern distance education in the teaching, we put forward the college sports support environment of multimedia network teaching platform structure[3-5], which is shown in figure 2: 


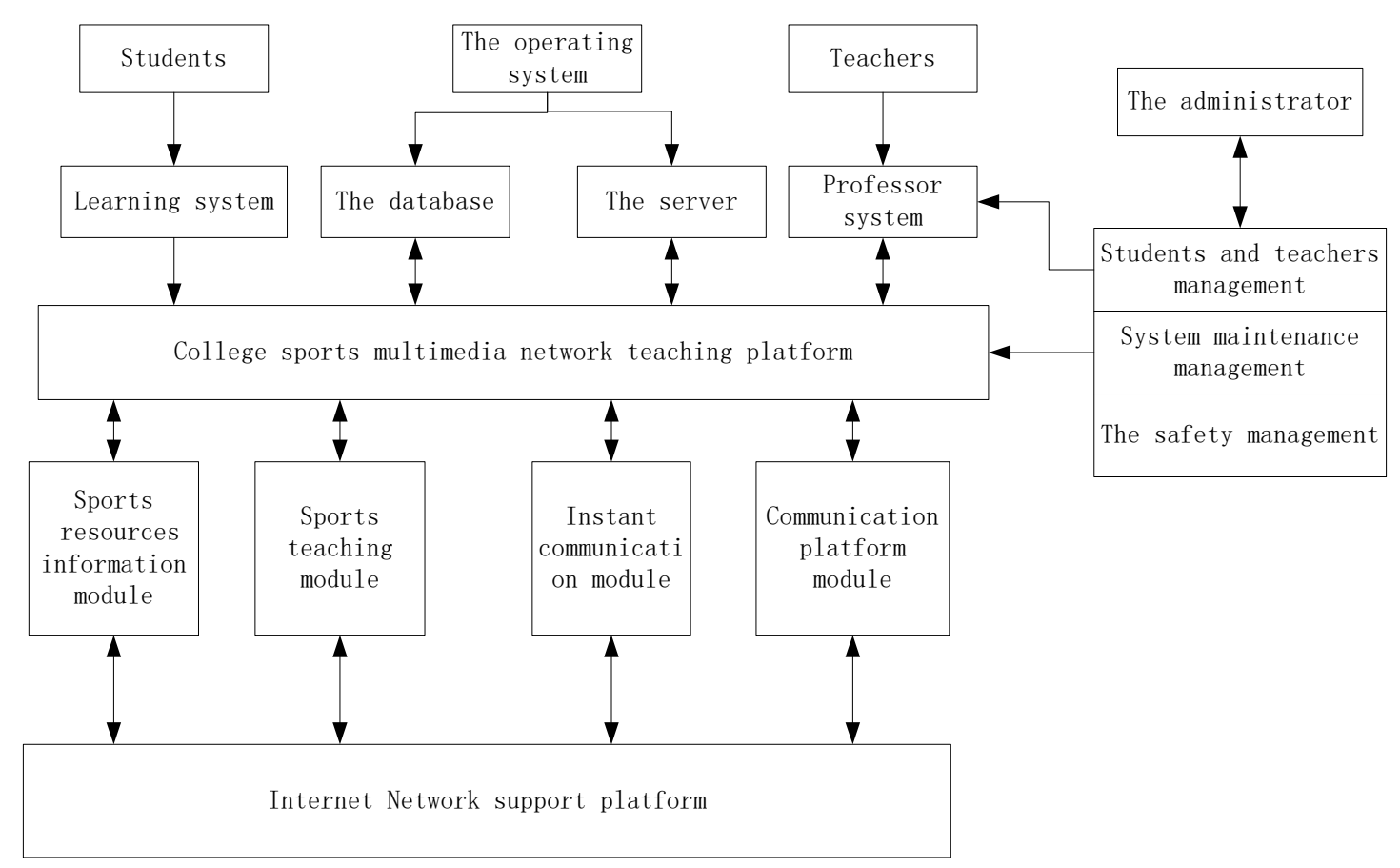

Fig. 2 The support environment structure of college sports multimedia network teaching platform

\section{College sports support environment of multimedia network teaching platform structure}

College sports support environment of multimedia network teaching platform structure. College students and teachers can understand the latest sports related information through the module, at the same time, they can watch all kinds of large-scale sports events online video. School also can use this module to release about the latest news and information related to sports school.

Sports teaching module. Sports teaching module is the core of the university sports multimedia network teaching platform module, whose main function is to display and assist in the process of sports teaching in colleges and universities. It contains the introduction of the course, electronic teaching materials, teaching lesson plans, multimedia network course ware, live video teaching, teaching (including show excellent courses), the curriculum resources collect ing etc. The logic structure and realization of live teaching under the sports teaching module is as shown in figure 3.

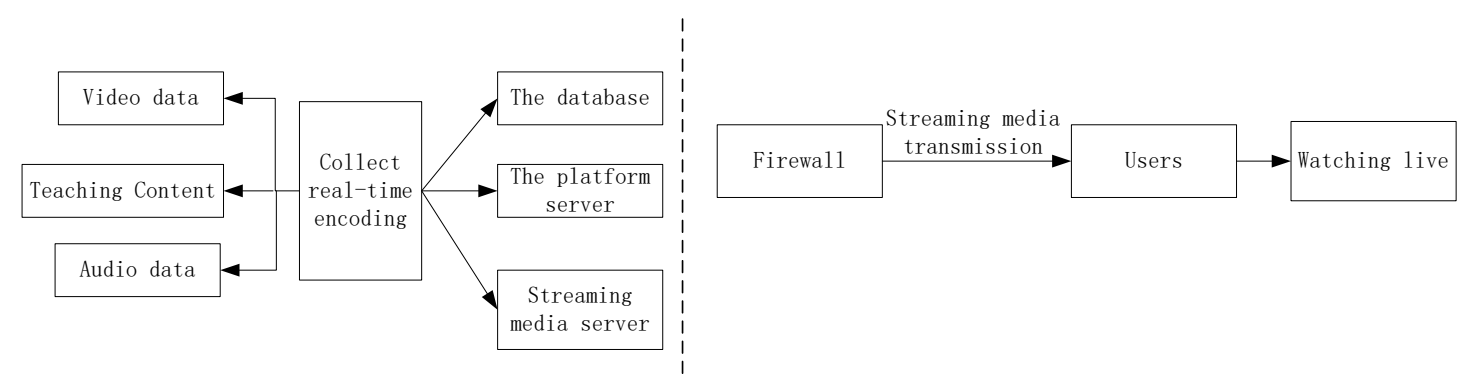

Fig. 3 Logical structure and realization of live broadcast of the teaching modules

Instant communication module. Instant communication module is main system which realizes the real-time communication of teaching information in the process of teaching, it can realize the real-time information communication between teachers and students, and it can be used for the students to disabuse and online instruction in time. Is also the main platform of expert guidance communication with sports fans.

Communication platform module. The main function of the module is through the electronic bulletin board, BBS, Email and online communication software to make that implementation for sports knowledge exchange and discussion. 


\section{Conclusions}

The application of multimedia network teaching in colleges and universities sports teaching in our country is still in its infancy. There are few school which owns multimedia network teaching platform in the true sense. Multimedia network teaching platform is a visualization system, and it is the whole of an application. True multimedia network teaching platform is not only data download, but also there is a strong function of multimedia teaching and real-time communication interactive learning function, and it can achieve the optimization and sharing of teaching resources. These are that the traditional university campus site doesn't have.

\section{References}

[1] BingZe Chen, etc., The Network Education And The Modern Sports Distance Education,(2004) No.4.(In Chinese)

[2] Wei Zheng Gong, Yu Xu, Research Of School Sports Network Curriculum Development Model Under The Environment of Distance Education, (2008) No.2.(In Chinese)

[3] Yin Ma, etc., The Complementary Advantages Of Combination Of Track and Field Teaching With Network Teaching,(2011) No.2.(In Chinese)

[4] Juan Xiao Wang, etc., Research Of The Application Of Network Education Technology In The Sports Teaching, (2010) No.11.(In Chinese)

[5] Fei Guang Luo, etc., The Application Research Of The Network Education Technology In The Sports Teaching,(2008) No.15.(In Chinese) 